\title{
DIE SAGD - SY ONTSTAAN EN ONTWIKKELING
}

KO C.M.L. Pretorius*

'An Army Medical Service is an indispensable technical branch of the military organisation. On its efficiency the manpower of an army to a great extent depends."

The military medical service has been given little consideration in the past. In 1912 the Union Defence Force was created and with it, the organisation of a new medical service. During the First World War medical personnel offered their services in South Africa, German East Africa and in several parts of Europe. In 1918 the death rate had been 42 per thousand, many as a result of the tropical and sub-tropical campaigns. At the end of the Second World War a world record was created by die SAMC during the East African Campaign. The death rate had then been less than two per thousand. After the war the Medical Service returned to its peace-time work.

Many recommendations have since then been accepted by the government and today the fourth arm of the SADF is formed by the Medical Service. It is commanded by a Lieutenant-general. Operational support facilities are also provided.

\section{Voorgeskiedenis}

Die doel van die Suid-Afrikaanse Geneeskundige Diens is om mediese en aanverwante ondersteuning aan die SAW te verleen. Om aan die doel te beantwoord, moet aan sekere vereistes voldoen word. Dit sluit die inskakeling van mediese ondersteuning by operasionele en ander aktiwiteite in.

Omdat die Weermag oor die afgelope dekades verstommend ontwikkel het, moes die SAGD ooreenstemmend tred hou.

In Suid-Afrika is daar in die Verdedigingswet (Wet No 13 van 1912) voorsiening gemaak vir die skepping van 'n mediese afdeling. Die doel van die wet was om 'n Unieverdedigingsmag daar te stel, bestaande uit 'n Staandemag, ' $n$ Aktiewe Burgermag en 'n Kadetorganisasie. Die totstandkoming van die mediese diens is aan Itkol M.C. Roland (onder-sekretaris van Verdediging) opgedra.

Die stigting van die SAGD is vergemaklik vanweë die feit dat daar reeds 3 mediese korpse (in Transvaal, Natal en die Kaap) in die Unie was. Hul lede, kennis en ervaring kon gebruik word.

Die Transvaal Medical Corps (TMC) het in 1903 ontstaan, met die doel om as 'n gespesialiseerde eenheid mediese hulp aan verskeie regimente op die Rand te gee. Lt-kol D.W. Johnston

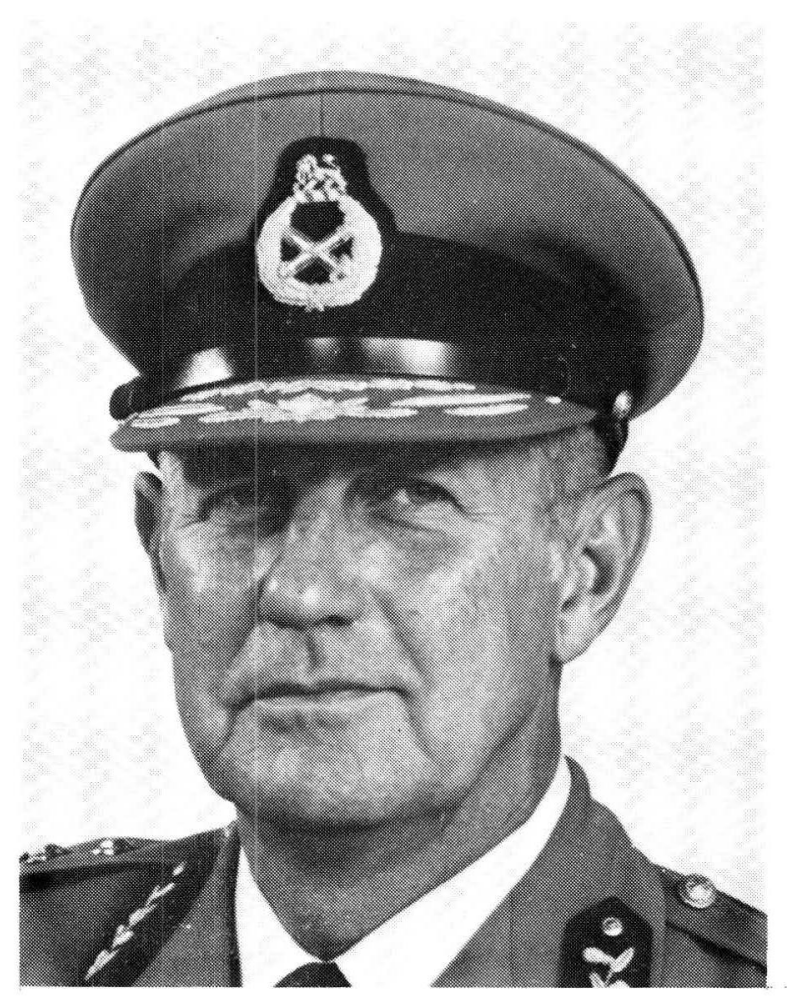

Lt-genl N.J. Nieuwoudt, SM Geneesheer-generaal sedert 31 Oktober 1977

(1903-1906), It-kol L. Sanson (1906-1908) en Itkol H.H. Balfour (1908-1912) was bevelvoerders. Verskeie hoogtepunte is beleef tydens die TMC se bestaan. Goedkeuring is in 1904 verleen vir die stigting van 'n Verpleegstersreserwe wat tydens oorlog en noodtoestande sou optree. 
'n Berede afdeling en ' $n$ fietsryerseksie is in 1905 toegevoeg en in 1906 het die korps aan die Natalse Rebellie deelgeneem.

Die Natal Volunteer Medical Corps (NMC) is in 1899 uit verskillende ambulansafdelings saamgestel. Lt-kol J. Hyslop was die bevelvoerder. Tydens die beleg van Ladysmith is lede van die korps as baardraers gebruik. Hulle is ook gemobiliseer vir die Zoeloe-opstand in 1906. Die hoofkwartier van die NMC was in Pietermaritzburg. Met die totstandkoming van die Mediese Diens in 1913, het die NMC uit 'scattered detachments' ${ }^{2}$ bestaan.

As Britse kolonies kon beide Natal en die Kaap voor 1899 staatmaak op die hulp en beskerming van Imperiale troepe, 'n klein koloniale mag en vrywilliger eenhede. Dr. John Ross het in 1886 'n tak van die Orde van St. Johannes van Jerusalem in King Williams Town gestig, wat weer gelei het tot die stigting van die eerste plaaslike militêre ambulansafdeling in 1887. Later het dit die Volunteer Medical Staff Corps geword. Hulle het aan die Betsjoeanalandveldtog (1897) deelgeneem en het ook 'n belangrike diens tydens die Anglo-Boereoorlog gelewer. Op 1 Januarie 1899 het hul naam verander na Cape Medical Staff Corps (CMC) met It-kol E.B. Hartley as bevelvoerder.

Slegs vrywilligers het as mediese personeel diens gelewer in die Anglo-Boereoorlog. Lede van die TMC, NMC, is daarvoor gewerf en hulle is aan baardraers aangewend. Volgens Sir William Wilson (in bevel van die Britse mediese organisasie) was net sommige van hulle opgelei. Die CMC is na die oorlog met die koning se vaandel beloon.

In 1903 is die taak aan It-kol Hartley opgedra om die vooroorlogse 'Medical Department' of Staandemagpersoneel en die vrywillige mediese eenhede te integreer en te organiseer.

Eers in 1912 is daar ' $n$ poging aangewend om 'n volwaardige militêre mediese afdeling daar te stel, met die aanvaarding van die Unieverdedigingswet. Na aanleiding van 'n navorsingsprojek het H.R.M. Bourne (later Sir Ronald) bekend gemaak dat die totstandkoming van 'n Suid-Afrikaanse Geneeskundige Diens wel moontlik was. Die stigting van die SAGD is vergemaklik omdat die genoemde plaaslike mediese korpse en veral die Royal Army Medical Corps hulp, leiding en lede kon verskaf. Die grootste taak is aan maj P.G. Stock as eerste bevelvoerder opgedra.
Hy het sy taak tweërlei benader. Eers moes reëls en regulasies vasgestel word en dan moes ondersoek ingestel word na die praktiese implimentering van die Geneeskundige Diens se organisasie. Maj Stock het nie veel tyd tot sy beskikking gehad nie, omdat die Staandemag in April 1913 en die Aktiewe Burgermag in Julie 1913 gestig is en mediese dienste verlang het. As noodmaatreël is die bestaande mediese korpse behou. Na sy skakeling met die St. Johannes en die Rooikruis, het maj Stock en sy beplanners besef dat hulle in oorlogstye nie alleen die mas sou opkom nie. Daar moes van alle beskikbare mediese personeel gebruik gemaak word, ook vroue in die Verplegingsdiens.

Die verskyning van die Staatskoerant van 3 Desember 1913 het die harde werk beloon. Daarin is die stigting van die SAGD, sy regulasies en organisasie uiteengesit. Soos die UVM, was die SAGD verdeel gewees in ' $n$ klein Staandemagen 'n groot Aktiewe Burgermag personeel.

Die Staandemagpersoneel is verdeel in 'n hoofkwartier (om die mediese organisasie, administrasie en opleiding van die Burgermageenheid te behartig), 'n opleidingsdepot (om opleidingsfasiliteite en opgeleide personeel te verskaf) en 'n voorradedepot (om bestaande voorrade te sentreer vir latere hergebruik). Dit het egter gou geblyk dat die Staandemagpersonnel nie die organisasie van die Burgermaglede kon behartig nie en voorsiening is gemaak vir adjunk-direkteure en assistent-direkteure vir die onderskeie militêre distrikte. Hulle was verantwoordelik vir militêre mediese aangeleenthede.

Die Aktiewe Burgermag se hooftaak was om in 'n oorlogsituasie die gewondes te verpleeg en af te voer. Sewe Brigade veldambulanse, 3 veldambulanse, 'n sanitêre seksie, 'n afvoerhospitaal, 'n ambulanstrein en 'n voorradedepot in Pretoria, het hulle bygestaan om hulle taak uit te voer. By elke regiment was daar ' $n$ mediese offisier om koördinasie te bewerkstellig.

Die Staandemag onder leiding van mense soos maj P.G. Stock, kol Knapp, kapt Welsh, kapt Cope en suster C. Dick (sy was die eerste vroulike lid van die UVM) het begin funksioneer. 'n Tekort aan personeel het hulle genoodsaak om mense by die Royal Army Medical Corps te leen en gaandeweg het hulle hul eie instrukteurs begin oplei. Vanaf 1913 het Tempe die Mediese Dienste se opleidingsentrum geword.

Die Burgermag was in 14 mediese eenhede ver- 
deel en hul hoofkwartiere was onderskeidelik in Kaapstad, Worcester, Port Elizabeth, Pietermaritzburg, Ladysmith, Johannesburg, Pretoria en Bloemfontein. Die eenhede was weer in militêre distrikte verdeel. Vanweë politieke onrus kon die mediese reorganisasieproses nie gedurende 1913 afgehandel word nie. Die werwing van rekrute vir die nuwe eenhede is ook tydelik agterweë gelaat. Maj. Stock het wel vrywilligers van die mediese korpse voor 1913 in die nuwe mediese opset ingedeel. 863 dokters is daarna as offisiere aangestel.

\section{Deelname van die SAGD aan die Eerste Wêreldoorlog (1914-1919)}

Op 4 Augustus 1914 het Suid-Afrika as 'n Britse dominium tot die oorlog toegetree. Die SAGD het op daardie stadium oor 2 berede brigade veldambulanse, 1 mediese kompanie, 2 veldambulanse, ' $n$ voorradedepot en ' $n$ geweldige personeeltekort (die Royal Army Medical Corps se hulp is onttrek) beskik. Ter voorbereiding is die berede brigade veldambulans in Pretoria op 'n gereedheidsgrondslag geplaas, militêre mediese eenhede is gemobiliseer en op sterkte gebring, hospitale is in gereedheid gebring en vervoer vir die afvoer van pasiënte (2 ambulanstreine is beskikbaar gestel) is gereël.

Die UVM het in Suidwes-Afrika, Duits Oos-Afrika en Europa aan die oorlog deelgeneem.

\section{Duits-Suldwes-Afrika}

Kol Knapp, as assistent-direkteur van die Geneeskundige Diens, het begin om Port Nolloth in SWA as basis van die mag se mediese organisasie op te rig. Hy is vergesel deur die berede brigade veldambulanse en hulle is gevolg deur die 9de berede brigade veldambulans teen die einde September. Die eerste veldambulans onder kapt J. Pratt-Johnson het in Lüderitzbucht aangekom en is as die Algemene Hospitaal Nommer 4 georganiseer.

Tydelike veldhospitaaltjies is by Steinkopf, Okiep, Anendus en Klipfontein ingerig. Pasiënte wat meer intensiewe behandeling moes ontvang, is per trein na Port Nolloth en dan op die hospitaalskip, die SS Ebani na Kaapstad afgevoer.

In Oktober 1914 het It-kol Maritz hom by die Duitse magte geskaar. Dr J.P. MacGregor wat vrywillig by die Geneeskundige Diens aangesluit het en na Maritz se mense moes omsien, het daarin geslaag om te ontsnap. Brig-genl Lukin kon nie alleen die mas opkom nie en was genoodsaak om terug te trek. Dit het veroorsaak dat die militêre mediese organisasie aan die noordelike grens van die Kaap verbrokkel het. Hospitale by Sandfontein en Okiep is gesluit. Toestande was haglik by Anendus en Klipfontein. Pasiënte, ook dié met maseis, is op komberse op die vloer gehuisves. Om die situasie te red, het It-kol P.G. Stock die organisasie aan die noordelike grens hersien. Die Rebellie is onderdruk en die SWA-veldtog hervat. Die Duitse magte was nie bestand teen die oormag nie.

Hoewel die ongevalle getal laag was, moes die Geneeskundige Diens oornag in 'n volwasse afdeling ontpop. Die waarnemende Minister van Verdediging, C.H. Mentz, loof hulle vir 'the excellent work you have done with us, all of it constructive and under the highest possible pressure'. ${ }^{3}$ Nog 'n bron gee aan hulle erkenning van hul werk, 'The Mounted Brigade Field Ambulances kept up and sustained the same marching records as the brigades to which they were attached'. ${ }^{4}$ Dit is lofwaardig as mens die lang onherbergsame terrein waaroor afvoer moes geskied, in ag neem.

\section{Duits Oos-Afrika}

In Duits Oos-Afrika het sake anders verloop. Die terrein en klimaat het van die Kolonie 'n gedugte teenstander gemaak en Duitsland wou die Kolonie ten alle koste behou. $\mathrm{Na}$ ' $\mathrm{n}$ ondersoek in die Unie is besluit om ' $n$ algemene hospitaal, drie veldambulanse, vyf berede brigade veldambulanse, twee sanitêre seksies, twee Kompanies Indiër draagbaardraers, 'n tandheelkundige eenheid en 'n voorradedepot na Duits OosAfrika te stuur.

Vroue is as Verpleegpersoneel na Duits OosAfrika gestuur. Hulle het baie ontberinge deurgemaak en moes met min geriewe klaarkom. Die Suid-Afrikaanse Verplegingsdiens het gedurende 1914 ontstaan en is die enigste vroue organisasie van die Weermag wat deur al die jare onafgebroke bly bestaan het.

G.D. Hunter van die Royal Army Medical Corps was in Duits Oos-Afrika in bevel van die mediese dienste. Sy hoofkwartier was in Nairobi. Hy het besef dat Oos-Afrika se ongesonde klimaat (siektes soos bosluiskoors, malaria, disentrie en swartwaterkoors) gevaar vir die soldate ingehou 
het en het gereël om ongevalle na Kaapstad af te voer.

Die Suid-Afrikaanse Algemene Hospitaal is by Kedongal ingerig. Drie divisies en verskeie kommunikasieroetes is deur die Suid-Afrikaanse eenhede bedien. ' $n$ Assistent-direkteur mediese dienste is aan die hoof van elke divisie geplaas om die mediese reëlings aan die front te laat vlot. Die mediese organisasie is egter nie na waarde geskat nie. Hulle is nie altyd op hoogte gehou van die Opperbevel se besluite nie en kon dan nie self hul optrede beplan nie. Toestande het vererger as gevolg van die reënseisoen.

Volgens genl J.C. Smuts 'it became more and more a campaign against climate, geographical conditions and disease'. ${ }^{5}$ Veldambulanse is in hospitale omskep. Die Ebani, Vita en later 'Professor Woerman' is as ambulansskepe gebruik om die talle ongevalle af te voer.

Lt-kol G.H. Knapp het in die Unie waargeneem as Direkteur Mediese Dienste. Hy moes personeel en toerusting vir die veldtog voorsien. Sy taak is bemoeilik as ons na omstandighede binne die Unie op daardie stadium kyk. Die meeste lede het deelgeneem aan die oorlog en dit het 'n personeeltekort veroorsaak. Nommer Twee Algemene Hospitaal, Maitland, is ingerig om nog huisvesting vir pasiënte te verskaf. $\mathrm{Pa}$ siënte is van die dokke af per trein en per ambulans na die hospitale vervoer. Teen September 1917 kon die hospitale in die Unie nie meer al die Oos-Afrikaanse pasiënte huisves nie. Die toestand het kritiek geraak. Kol Stock is terug ontbied van Europa af. Hy het tydelike- en tenthospitale opgerig om die probleem die hoof te bied. Dit is ook tydens die 1918 Griepepidemie in die Unie gebruik. Teen September 1918 kon Oos-Afrikaanse gevalle weer hanteer word tot 1919 , toe die stryd beëindig is.

\section{Europa}

1 Suid-Afrikaanse Veldambulans en 1 Suid-Afrikaanse Algemene Hospitaal is na Europa gestuur. Van Brittanje af is Suid-Afrikaanse Veldambulans na Egipte gestuur. Tydens die bootrit het hulle troepe ingeënt teen cholera en ingewandskoors. Aan die oorlog self het hulle nie deelgeneem nie. 'Die enigste lede van die veldambulans wat eersthandse kennis van die veldtog. teen die Sanusi opgedoen het, was ' $n$ groepie wat voertuie na die front moes neem. ${ }^{5}$ In April 1916 het hulle na Frankryk teruggekeer.
1 Suid-Afrikaanse Algemene Hospitaal is by hulle aankoms in Brittanje tydelik by Imperiale Hospitale en Richmond Park ingedeel. Vandaar het hulle na Frankryk vertrek. Hulle het hier met verskeie probleme te kampe gehad, soos die swak weersomstandighede, gebrekkige skuilings, lang en onbegaanbare verbindings, skerpskutters, gas, artillerie en vliegtuie, lawaai, chaos, versperrings en hul gebrek aan kennis oor loopgraafoorlogvoering. 'Hul werk moes dikwels onder hewige artillerievuur gedoen word en her meer behels as net blote veldverpleging'7 Verskeie van die veldambulanspersoneel is met medaljes beloon vir persoonlike dade van dapperheid.

\section{Die volgende getuig van dle sukses wat behaal is:}

Gebrekkige akkommodasie het hulle genoop om hutte op te rig. Skuifdeure is vir tente ontwerp en houtvloere en stofies het vir die koue Europese winter gehelp. Lede van die Suid-Afrikaanse Verplegingsdiens het die groot personeeltekort help aanvul. 'n Groot aantal ongevalle met beenbreuke is behandel en die metode was so suksesvol, dat dit deur die Britse Leër oorgeneem is. Die sielkundige gevolge van die oorlog is ook raakgesien. ' $n$ Korpsrusoord is vir oorlogsmoë soldate daargestel. By Richmond is begin met vakopleiding vir soldate wat deur die oorlog liggaamlik gestrem was. Vir hulle het dit nuwe hoop vir die toekoms geskep.

\section{Dle Tussentydperk en Feorganisasle}

Die SAGD is na die Eerste Wêreldoorlog as 'n aparte afdeling georganiseer. Die regering het in Februarie 1920, met die aftrede van kol P.G. Stock, besluit om die mediese afdeling by Departement van Volksgesondheid in te skakel. In vredestyd sou die pligte van die Direkteur Mediese Dienste deur ' $n$ offisier van die Departement Voksgesondheid uitgevoer word. In oorlogstyd sou hy onthef word van siviele aangeleenthede en kon hy net op sy millitêre werk konsentreer.

Die Unieverdedigingsmag se mediese afdeling was nou 'n definitiewe deel van die Staandemag, maar is beheer (behalwe tydens oorlog) deur die Departement van Volksgesondheid. Die sisteem het nouer samewerking en dus groter sukses geimpliseer.

Vir mediese personeel is vrywillige opleiding by Robertshoogte en Wynberg aangebied, omdat die militêre mediese skool by Robertshoogte gesluit was. 
Die verspreiding en voorsiening van voorrade namens alle regeringsdepartemente is beheer deur die Sentrale Mediese en Veeartseny-depot by die Artilleriebarakke.

Die wysiging van die Verdedigingswet in 1922 het voorsiening gemaak vir die reorganisasie van die Staandemag, wat 'n personeelsterkte van vier mediese offisiere en 44 ander range gehad het. Opleidingskampe is by Ladysmith, Grahamstad en Potchefstroom gestig. Die daarstelling van ' $n$ higiëne afdeling het in ' $n$ belangrike behoefte voorsien.

Die pligte van die SAGD het dus op hierdie stadium die ondersoek van soldate, die sanitasie van kampe, die verpleging van pasiënte in militêre hospitale en die opleiding van lede behels. 'n Hoogtepunt was die opening van die nuwe hospitaal in Robertshoogte in Oktober 1930. Gedurende 1936 het die hospitaal in Wynberg gesluit.

\section{Die SAGD se betrokkenheid in die Tweede Wêreldoorlog (1939-1945)}

'The outbreak of war in 1939 proved the calibre of the medical profession in general and the SAMC in particular. ${ }^{18}$ Op hierdie stadium het die, SAGD by uitstek as ' $n$ vredestydse organisasie gefunksioneer.

As gevolg van personeel en organisatoriese probleme is die Direktoraat Geneeskundige Dienste op 20 Desember 1939 losgemaak van die Departement van Volksgesondheid. Kol. A.J. Orenstein is aangestel as voltydse Direkteurgeneraal. Omstandighede het belowend gelyk. Vyf-en-twintig nuwe eenhede is gestig en 'n geslaagde toer is onderneem om personeel te werf. Aan die einde van 1940 was daar 249 mediese en 25 tandheelkundige offisiere vir operasionele doeleindes opgelei.

Kol Orenstein het die mediese dienste op 'n gereedheidsgrondslag geplaas. Hy het mediese toerusting, voertuie en voorrade bestel. Voorsiening is gemaak vir voldoende hospitaalfasiliteite. Die Amra sou as hospitaalskip diens doen. Sy pogings het die wind van voor gekry tydens die Griepepidemie van 1940. Die personeelsituasie het versleg. Voorrade kon nie van die buiteland verkry word nie. Dit is toe tuis vervaardig en die projek was baie suksesvol.

Sekere organisatoriese veranderings het ook nou plaasgevind. Die Direkteur Mediese Dienste kon nie meer alleen die mas opkom nie. Die Mediese Advieskomitee is ontbind en vervang deur 'n kleiner adviesraad wat deskundiges was op die gebied van higiëne, tandheelkunde, gesondheid, hospitale, personeelsake en bevoorrading.

\section{Oos-Afrika en Abbisinië}

Vyf mediese eenhede het eers in 1940 na die gevegsfront in Oos-Afrika vertrek, met kol Orenstein as Direkteur Mediese Dienste. Dit het 4 Algemene Hospitaal, een Mobiele Laboratorium, 5 en 6 Afvoerhospitale en ' $n$ voorradedepot ingesluit. Tydens die beplanningsfase het kol Orenstein faktore in ag geneem, soos die geografie, klimaat, die omstandighede van die plaaslike bevolking, die beskikbaarheid van water en die teenwoordigheid van gevaarlike tropiese siektes. 'When South Africa was preparing to send her soldiers on their first mission, chasing the Italian aggressor out of Abyssinia, Medical Services were tackling a problem which would have forced many less courages men into abject surrender. ${ }^{9}$ Baie is geleer uit probleme wat in die Eerste Wêreldoorlog opgeduik het.

Die hoofkamp te Gilgil en die nommer 4 SuidAfrikaanse Algemene Hospitaal by Nyeri, was in gebiede geleë wat relatief vry van malaria was. Die siektesyfer en gevegsverliese getalle was laer as wat aanvanklik gedink was. Slegs 850 per 1000 troepe per jaar het siek geword. Vir een gevegsverlies was daar 4 ongevalle as gevolg van tropiese siektes. Die lae standaard van die sanitasie en higiëne seksies het bygedra tot die siektesyfer.

Die hoofeenhede van die SAGD was soos volg versprei, 10 Suid-Afrikaanse veldambulanse was tussen Habaswein en Melka Galla saam met die Suid-Afrikaanse Infanterie Brigade, 11 en 12 Suid-Afrikaanse veldambulanse was saam met een Suid-Afrikaanse Divisie by Isiolo en Marsabit en 15 Suid-Afrikaanse veldambulans was tussen Gilgil en Mombassa. Hulle het hul plig onder moeilike omstandighede, in gietende reën, koue, uitputting en blootstelling uitgevoer. Die behandeling van siekes en gewondes moes in die veldambulanse geskied. Algemene praktisyns het dikwels operasies in die ambulanse uitgevoer omdat snydokters net nie beskikbaar was nie. Daar was 'n gebrek aan bloedoortappingsfasiliteite en varswatervoorrade. Waardevolle gebuite mediese voorrade wat 'n uitkoms gebied het, is deur eie magte vernietig voordat 
die mediese dienste dit kon voorkom. Die pasiënte is later in 3-ton vragmotors afgevoer omdat die ambulanse in die woestyn ondraaglik warm was en maklik in die los sand vasgesit het.

Mediese personeel is wanaangewend, omdat hulle vir lang tydperke by dieselfde eenhede ingedeel was. Die sukses wat wel behaal was, is slegs toe te skryf aan die inisiatief en energie van die eenheidsbevelvoerders.

\section{Noord-Afrika}

Brig Orenstein moes in Noord-Afrika voor bereid wees op 2 soorte oorlogvoerings, naamlik kontinuë beweging of die besetting van strategiese posisies. Mediese eenhede wat hier aan die oorlog deelgeneem het, was 10-, 11-, 14-, 15-, 16-, 17-, en 18 Suid-Afrikaanse veldambulanse. Hulle het saam met 1 en 2 Suid-Afrikaanse Divisies beweeg. Nommers 4 en 5 Suid-Afrikaanse Algemene Hospitale het in Egipte en nommer 6 Suid-Afrikaanse Algemene Hospitaal het in die Midde Ooste diens gelewer.

Kommunikasie tussen die veldambulanse en die hoofkwartier was soos dikwels in die verlede ' $n$ probleem. Kol R.J.W. Charlton (bevelvoerder van 11 Ambulans) het in ' $n$ verslag daarvan melding gemaak. 'My personnel have twice been left behind by withdrawing infantry, no warning of an impending move having been received. ${ }^{10}$

Die personeel- en ambulanstekort het groot afmetings begin aanneem. Verpleegsters is in hospitale, ambulanstreine en vliegambulanse aangewend. Dit het die tekort help aanvul. 'n Oor-, neus- en keelspesialis en 'n optalmiese spesialis is ook by 11 veldambulans ingedeel. Oor die algemeen was die gesondheid van die Suid-Afrikaanse soldate goed. Malaria, beserings, hitte uitputting, disenterie en velinfeksies was verantwoordelik vir die ongevalle wat daar was. Nadat die Suid-Afrikaanse uniforms in 1941 vervang is deur meer geskikte uniforms vir die woestynklimaat, het baie van die siektes verdwyn.

$\mathrm{Na}$ die herorganisasie van die SAGD, is drie veldambulanse per Divisie behou. Chirurgiese en mediese toerusting en ' $n$ afvoerhospitaal is naby die gevegslyn ingerig. Dit het meer doeltreffende mediese dienste in die hand gewerk. Nog ' $n$ verbetering wat aangebring is, het die standaard motorambulans verander. Meganiese ventilasie, 'n groter stofdigtheid en 'n swaarder tipe band vir die woestyntoestande het die afvoer van pasiënte aansienlik vergemaklik. Die veldambulanse kan met reg beskou word as die belangrikste mediese eenheid in die veld.

\section{Italië}

6 SA Pantserdivisie in Italie is ondersteun deur 1 en 2 SA Herstellingsoord, 102, 106, 107 en 108 SA Algemene Hospitaal, 1 en 2 SA veldoperasie-eenhede, 19 en 20 SA veldambulanse, Higiëniese seksies, Tandheelkundige eenhede en 'n Afvoerhospitaal. Verskeie lede van die Mediese Diens het ook saam met die Suid-Afrikaanse Lugmag opgetree.

6 SA Pantserdivisie was nie bekend met die snelbewegende tipe oorlogvoering wat hier gevoer is nie. Druk verkeer is op die paaie suid van Rome ondervind en met die aanval op Florence het dit veroorsaak dat die voorverbandposte nie altyd voldoende dekking kon verskaf nie. Die gebrek aan kommunikasie tussen die Adjunk-direkteur Geneeskundige Dienste en die Brigades het ook veroorsaak dat voorverbandposte onnodig verskuif is.

Reorganisasie van die mediese eenhede het net voor die winteroffensief 'n aanvang geneem. Weereens is talle probleme ondervind gedurende die gevegte. Behalwe gewondes, is siviele pasiënte ook behandel en het verskeie myn-ongevalle voorgekom. Die ambulanse was ontoereikend en is vervang deur Jeep-ambulanse wat meer geskik was vir die heuwelagtige topografie. Die Jeep was toegerus met rakke vir 2 of 4 draagbare met seilkappe bo-oor. Gewondes is per vliegtuig afgevoer. Verskeie gevalle van 'trench Foot' is aangemeld. In die sneeu en intense koue het die mediese dienste gebruik gemaak van sleë en ambulanse wat in kettings beweeg het, om pasiënte af te voer. 'n Behoefte aan klein beweeglike mediese spanne het hierdeur ontstaan.

Nadat vrede gesluit is, het verskeie mediese eenhede, onder andere 19 SA veldambulans nog tot Mei 1946 gefunksioneer voordat dit ontbind is.

\section{Madagaskar}

Die SAGD was nie veel betrokke by die veldtog in Madagaskar nie, want binne 6 maande was dit suksesvol afgehandel en was die Kaapse seeroete beveilig. 
In Madagaskar is die mediese dienste van die Unie en Brittanje deur die Britse Assistent-direkteur Mediese Dienste gekoördineer. Die tropiese klimaat en temperature wat gewissel het tussen 64 en 80 grade, is in ag geneem. Tropiese en aansteeklike siektesyfers was hoog. Daarom het 'n malariadeskundige 101 Taakmag vergesel. Daar was nie altyd van sy dienste gebruik gemaak nie. Geslagssiektesyfers het toegeneem.

Die vyand het teruggeval. 'n Tydelike hoofverbandplek is by Maromandia ingerig, nadat 19 $S A$ veldambulans met 'n motorambulanskonvooi deur ' $n$ vol rivier gestuit is. Siektes en gewondes is saamgedra deur ' $n$ besmette malaria omgewing. Hulle het snags deur moerasse en vleie gestap. Die mediese toerusting was onvoldoende en die tente geweldig warm.

' $n$ Mediese raad het siekte- en herstelverlof hersien en aanbevelings gemaak. Samevattend kan ons sê, dat die mediese diens hulle ook hier goed van hul taak gekwyt het.

\section{Demobilisasie na die oorlog en die ontwikkeling van moderne tendense}

Die proses het snel verloop. Personeel is gedemobiliseer en toerusting, geboue en eiendomme is verkoop en teruggegee.

Die groot aantal SA soldate wat uit Duitse Krygsgevangeniskampe vrygelaat is, het die SAGD in 'n nuwe krisis gedompel. Hulle moes medies geskik verklaar word voordat hulle weer opgeneem kon word in die samelewing.

'n Vaste fondament is vir die SAGD se vredestydse organisasie geskep. Twee militêre hospitale is permanent in Voortrekkerhoogte en in Kaapstad gevestig. Die SAGD het weer uit 'n Staandemag-afdeling en 'n Aktiewe Burgermagafdeling bestaan, met ' $n$ Direkteur-generaal aan die hoof. Die Staandemagelement het uit 'n aantal goed gesentreerde kommandemente bestaan. Die Burgermag het een mediese bataljon per divisie beskikbaar gestel. Die mediese dienste is verdeel in ' $n$ ligte veldambulans, hospitale, 'n senior mediese brigadegroep, Mediese en veeartsenystore, opleidingspersoneel en afdelings vir die SA Lugmag.

'n Tydperk van stagnasie het in 1948 ingetree. Vrywilligers het al hoe minder geword en min is op regeringsvlak vir die SAGD gedoen. In Maart 1919 het die naam van Direkteur-generaal van Geneeskundige Diens na Geneesheer-generaal
(GG) verander. Die Verplegingsdiens het in 1950 'n integrerende deel van die staandemag geword, Daar is in 1957 begin met die stigting van 'n gesondheidsdiens en die SA Vloot het ook 'n mediese diens gekry.

Kol Raymond is in 1959 deur brig Rauch vervang. Dit het 'n statusverlaging in die mediese diens geïmpliseer. 'n Moeilike tydperk het aangebreek. Personeel is nie gewerf nie en geen voorrade is aangekoop nie.

Die deelname van ' $n$ mediese seksie saam met 2 Eskader in Korea, het meegebring dat die belang van lugvaartgeneeskunde en die ondersoek van lugbemanning besef is. Die Sentrale Mediese Instituut by Lyttelton is daarvoor ingerig. In 1958 is 'n nuwe gebou te Voortrekkerhoogte betrek wat toegerus was met baie moderne apparaat. Opleidingskursusse het in 1957 aandag geniet. In die tydperk 1960-70 het die Instituut vir Lugvaartgeneeskunde fenomenaal gegroei. 'n Aantal gespesialiseerde afdelings soos sielkundige-, fisiologiese-, kardiologieseen pulmologiese afdelings het ook hulp na buite verleen en so bekendheid verwerf. Die nuwe lokaal te Verwoerdburg is in 1972 in gebruik geneem.

Vanweë die onbestendige wêreldpolitiek, het die SAW in 1960 ' $n$ waardering van hul militêre paraatheid en behoeftes aangevra. Dit het ' $n$ dinamiese groei en die implimentering van 'n nuwe beleid tot gevolg gehad, wat ook die SAGD betrek het. Die SAGD het tot 'n outonome ondersteuningsdiens gegroei en was op gelyke voet met die drie gevegsdienste, die Leër, Lugmag en Vloot. Die volwaardige weermagsdeel beskik tans oor sy eie vaandel, wapenskild, leuse en onderskeidingstekens.

Genl-maj E.C. Raymond, SSA, SM, het 'n belangrike bydrae gelewer tydens die militêre waardering in 1960, in die vorm van ' $n$ behoeftevasstelling van mediese voorrade.

Die hersiening van die Nasionale Dienspligstelsel het 'n groter las op die SAGD gelaai. Om die beste diens te kon lewer, is die nuwe SAGD Opleidingsentrum in 1965 gestig. Medisyne is na 1961 plaaslik vervaardig. 'n Nuwe militêre hospitaal is in Bloemfontein geopen. Ook op ons grense is operasionele paraatheid verhoog. Veldambulanse is by die bestaande voorraad gevoeg.

Die eerste belangrike organisatoriese verande- 
ring het ook in hierdie tyd plaasgevind. Die Geneesheer-generaal kon administratiewe beheer oor sy eie personeel uitoefen en het die Weermag se opperbevel geadviseer.

In 1969 is genl-maj Raymond deur It-genl C.R. Cockroft opgevolg. Hy het die behoefte van opleiding van sy personeel raakgesien. 1 Militêre Hospitaal te Voortrekkerhoogte is in ' $n$ opleidingshospitaal omskep. Verpleegsters en dokters is nou deur die Weermag self opgelei. ' $n$ Veldtog teen die misbruik van dwelmmiddels in die SAW is ook van stapel gestuur.

Die SAGD se bostruktuur het verander. 'n Pos vir ' $n$ It-genl en 2 poste vir 'n Adjunk-geneesheergeneraal is ingestel.

Toenemende operasionele ingesteldheid het al hoe meer noodsaaklik geword, soos die SAGD se betrokkenheid in die Angolese Burgeroorlog (operasie Savannah 1975-76) bewys. Mediese-, veeartseny-, tandheelkundige-, aptekers- en ander dienste is gelewer. Mediese ordonnanse, verpleegoffisiere en radiografiste was betrokke. Ongevalle is in nat weersomstandighede behandel en in die nag oor lang afstande per lug vervoer. Mediese bystand is ook aan die plaaslike gemeenskap en ongeveer 4000 Angolese vlugtelinge gegee. Probleme is tydens die operasie met logistiek en kommunikasie ondervind.

Lt-genl N.J. Nieuwoudt, SSA, SM, het sy voorganger in 1977 opgevolg. Hy is tans nog Geneesheer-generaal. Die SAGD is vanaf 1977 al meer uitgebou tot ' $n$ outonome weermagsdeel. In 1978 het organisatoriese veranderinge meegebring dat ' $n$ stafbeenstelsel ingestel is. Die voordeel was dat kommunikasielyne verkort is as gevolg van die desentralisering van gesag na laer vlakke. Die burgerlike mediese potensiaal is benut deur middel van Kommandemente. In 1979 is begin met die opleiding van die eerste groep vrouerekrute. Hulle is opgelei in dril, skiet-, veldkuns, kaartlees, radio-spraakprosedures en mediese opleiding. 'Die eintlike doel is om die meisies meer volwasse en positief tot die Weermag die wêreld in te stuur en om die manlike element op die tuisfront te kan aflos. ${ }^{111}$

Die SAGD neem steeds deel aan militêre operasies en 'n ondersoek is geloods na die moreel van soldate in die operasionele gebied. ' $n$ Vloot
Mediese Sentrum het in 1978 begin om duikers en ander vlootpersoneel medies te ondersteun. In Februarie 1979, is die Militêre Hospitaal te Wynberg geopen en 'n mediese opleidingskommandement het in Januarie 1980 noodsaaklike dienste begin lewer.

Die SAGD het tot ' $n$ outonome ondersteuningsdiens gegroei en was op gelyke voet met die gevegsdienste, die Leër, Lugmag en Vloot. Hul funksie het deur al die jare heen dieselfde gebly. Dit het net meer gespesialiseerd geraak om sodoende saam met die tye te verander. In die woelinge van ons tyd is dit 'n noodsaaklike funksie wat nie verwaarloos kan word nie. Die SAGD vervul voorwaar 'n roeping.

Ko C.M.L. Pretorius, BA (HODG) Skoolbiblioteekkunde, is verbonde aan die Militere Informasieburo van die SAW.

\section{Voetnotas}

1. Encyclopaedia Britannica inc., Encyclopaedia Britannica Vol 5, 1948 , Chicago, p. 186-187.

2. SAW-Argief, Argiefgroep D C Houer 1295, Leêr 1773, Organisation of Medical Services, Brief 1/1773, Onder-Sekretaris van Verdediging, Minister van Verdediging, Pretoria, Augustus 1912.

3. SAW-Argief, Argiefgroep Eenheidsleêrs, P.G. Stock, Brief, H Mentz-P.G. Stock, Kaapstad, 31 Maart 1926.

4. Official History: The Union of South Africa and the Great War 1914-18.

5. W.G. Macpherson: History of the Great War. Medical Services. General History, Vol 4 p. 416

6. SAW-Argief, Argiefgroep Eenheidsleêrs: Een Veldambulanseenheid, $S A G D$, Verslag deur maj C.M. Murray, Kaapstad p. 5.

7. Ibid., p. 9.

8. Narratives and UNF0 12/13: 11178-11351. (11328 South African Medical Corps) p. 4

9. The Nongqai June 1942: The U.D.F. Medical Directorate - Sir E.N. Thornton p. 649.

10. U/MED/23/2/5, First Division Operations: Operations Report, dd 25 Desember 1941, p. 4.

11. Koerant: Die Oggendblad, Dinsdag 19 Januarie 1982

\section{Bibliografie}

1. Buchan J. The South African forces in France. London, 1920.

2. Collyer J.J. Die Suid-Afrikaners met generaal Smuts in Duits Oos-Afrika 1916. Pretoria 1939.

3. Koerant: Die Oggendblad. 19 Januarie 1982

4. Laffin J. Surgeons in the Field. London, 1970.

5. Macpherson W.G. History of the Great War. Medical Services, General History Vol. 2. London.

6. Martin H.J. South Africa at War Vol. 7. Cape Town, 1979

7. Narratives and UNFO 12/13. 11178-11351.

8. Official History. The Union of South Africa and the Great War 1914-18.

9. Orpen N. South African Forces World War 2 Vol. 1. East African and Abyssinian Campaigns. Cape Town, 1968.

10. Cipen N. South African Forces in World War 2 vol. 5. Victory in Italy. Cape Town, 1975

11. Orpen N. The Sidi Rezegh Battles 1941.

12. Orpen N. War in the Desert.

13. SAW-Argief. Argiefgroep. DC Houer 1295, Leêr 1773, Organisation of Medical Services.

14. SAW-Argief. Argiefgroep. Eenheidsleêrs, P.G. Stock, Brief H. Mentz, P.G. Stock.

15. SAW-Argief. Argiefgroep. Eenheidsleêrs: 1 Veldambulanseenheid, SAGD

16. Tydskritte: The Nongqai June 1942, August 1943. 